\title{
Optical Frequency Optimization of a High Intensity Laser Power Beaming System Utilizing VMJ Photovoltaic Cells
}

Daniel E. Raible and Dragos Dinca

Glenn Research Center, Cleveland, Ohio

Taysir H. Nayfeh

Cleveland State University, Cleveland, Ohio 


\section{NASA STI Program . . . in Profile}

Since its founding, NASA has been dedicated to the advancement of aeronautics and space science. The NASA Scientific and Technical Information (STI) program plays a key part in helping NASA maintain this important role.

The NASA STI Program operates under the auspices of the Agency Chief Information Officer. It collects, organizes, provides for archiving, and disseminates NASA's STI. The NASA STI program provides access to the NASA Aeronautics and Space Database and its public interface, the NASA Technical Reports Server, thus providing one of the largest collections of aeronautical and space science STI in the world. Results are published in both non-NASA channels and by NASA in the NASA STI Report Series, which includes the following report types:

- TECHNICAL PUBLICATION. Reports of completed research or a major significant phase of research that present the results of NASA programs and include extensive data or theoretical analysis. Includes compilations of significant scientific and technical data and information deemed to be of continuing reference value. NASA counterpart of peer-reviewed formal professional papers but has less stringent limitations on manuscript length and extent of graphic presentations.

- TECHNICAL MEMORANDUM. Scientific and technical findings that are preliminary or of specialized interest, e.g., quick release reports, working papers, and bibliographies that contain minimal annotation. Does not contain extensive analysis.

- CONTRACTOR REPORT. Scientific and technical findings by NASA-sponsored contractors and grantees.
- CONFERENCE PUBLICATION. Collected papers from scientific and technical conferences, symposia, seminars, or other meetings sponsored or cosponsored by NASA.

- SPECIAL PUBLICATION. Scientific, technical, or historical information from NASA programs, projects, and missions, often concerned with subjects having substantial public interest.

- TECHNICAL TRANSLATION. Englishlanguage translations of foreign scientific and technical material pertinent to NASA's mission.

Specialized services also include creating custom thesauri, building customized databases, organizing and publishing research results.

For more information about the NASA STI program, see the following:

- Access the NASA STI program home page at http://www.sti.nasa.gov

- E-mail your question via the Internet to help@ sti.nasa.gov

- Fax your question to the NASA STI Help Desk at $443-757-5803$

- Telephone the NASA STI Help Desk at 443-757-5802

- Write to: NASA Center for AeroSpace Information (CASI) 7115 Standard Drive Hanover, MD 21076-1320 


\section{Optical Frequency Optimization of a High Intensity Laser Power Beaming System Utilizing VMJ Photovoltaic Cells}

Daniel E. Raible and Dragos Dinca

Glenn Research Center, Cleveland, Ohio

Taysir H. Nayfeh

Cleveland State University, Cleveland, Ohio

Prepared for the

International Conference on Space Optical Systems and Applications (ICSOS)

sponsored by the Institute of Electrical and Electronics Engineers

Santa Monica, California, May 11-13, 2011

National Aeronautics and

Space Administration

Glenn Research Center

Cleveland, Ohio 44135 


\section{Acknowledgments}

This work was conducted by the Industrial Space Systems Laboratory (ISSL) at Cleveland State University under grant from the AFRL-Revolutionary Munitions Directorate at Eglin Air Force Base. In addition, the ISSL team would like to express their thanks to: Bernie Sater and Greenfield Solar, for the advice given to the ISSL from years of experience developing the VMJ cells. Jim Soeder, Ray Beach, Fred Wolff and the NASA Glenn Research Center for supporting the efforts of the ISSL. Ken Edwards and the Eglin Air Force Research Laboratory for the research partnership with the ISSL in further developing this technology. Hobson Lane, Bob Rice and Northrop Grumman’s Space Technology division for the time and support given to the ISSL during the demonstration. LIMO Inc. for accommodating the ISSL team during the experimental tests and visit of the facilities in Dortmund, Germany.

Trade names and trademarks are used in this report for identification only. Their usage does not constitute an official endorsement, either expressed or implied, by the National Aeronautics and Space Administration.

Level of Review: This material has been technically reviewed by technical management.

Available from

NASA Center for Aerospace Information 7115 Standard Drive Hanover, MD 21076-1320
National Technical Information Service 5301 Shawnee Road Alexandria, VA 22312 


\title{
Optical Frequency Optimization of a High Intensity Laser Power Beaming System Utilizing VMJ Photovoltaic Cells
}

\author{
Daniel E. Raible and Dragos Dinca \\ National Aeronautics and Space Administration \\ Glenn Research Center \\ Cleveland, Ohio 44135 \\ Taysir H. Nayfeh \\ Cleveland State University \\ Cleveland, Ohio 44115
}

\begin{abstract}
An effective form of wireless power transmission (WPT) has been developed to enable extended mission durations, increased coverage and added capabilities for both space and terrestrial applications that may benefit from optically delivered electrical energy. The high intensity laser power beaming (HILPB) system enables long range optical "refueling" of electric platforms such as micro unmanned aerial vehicles (MUAV), airships, robotic exploration missions and spacecraft platforms. To further advance the HILPB technology, the focus of this investigation is to determine the optimal laser wavelength to be used with the HILPB receiver, which utilizes vertical multi-junction (VMJ) photovoltaic cells. Frequency optimization of the laser system is necessary in order to maximize the conversion efficiency at continuous high intensities, and thus increase the delivered power density of the HILPB system. Initial spectral characterizations of the device performed at the NASA Glenn Research Center (GRC) indicate the approximate range of peak optical-to-electrical conversion efficiencies, but these data sets represent transient conditions under lower levels of illumination. Extending these results to high levels of steady state illumination, with attention given to the compatibility of available commercial off-the-shelf semiconductor laser sources and atmospheric transmission constraints is the primary focus of this paper. Experimental hardware results utilizing high power continuous wave $(\mathrm{CW})$ semiconductor lasers at four different operational frequencies near the indicated band gap of the photovoltaic VMJ cells are presented and discussed. In addition, the highest receiver power density achieved to date is demonstrated using a single photovoltaic VMJ cell, which provided an exceptionally high electrical output of $13.6 \mathrm{~W} / \mathrm{cm}^{2}$ at an optical-to-electrical conversion efficiency of 24 percent. These results are very promising and scalable, as a potential $1.0 \mathrm{~m}^{2}$ HILPB receiver of similar construction would be able to generate $136 \mathrm{~kW}$ of electrical power under similar conditions.
\end{abstract}

\subsection{Introduction}

The concept of wireless power transmission has been around for almost two centuries, beginning with Callan and Marconi, but it was the pioneering work of Nikola Tesla that furthered the reality of this concept around the turn of the twentieth century (Ref. 1). Following Tesla's pioneering work, microwave technology refined during and after the second world war became the primary means of exploring wireless power transmission. Although microwave technology is capable of delivering massive amounts of energy, its efficiency and practical use become limited when utilized over longer distances due to diffractive losses. Inductive transfer is another form of wireless power transmission, and may be found in applications such as charging small hand held devices. This form of power transmission, however, is generally only effective over small distances (cm or less). With the development of high power semiconductor lasers along with advances in photovoltaic cell technology, a new avenue in the realm of wireless power transmission has been opened for research and development.

HILPB is a relatively new technology which has been developed to enable long range wireless power transmission for both space and terrestrial applications. The foundation and potential practical use of HILPB is based on high wall-plug efficiency lasers, specialized photovoltaic cells and the proven technological ability to accurately direct optical energy over long distances (kilometers or greater) with demonstrated systems such as the Airborne Laser (ABL), Tactical High Energy Laser (THEL), and various free-space optical communication systems. Applications that may utilize optically delivered electric energy include robotic exploration, airships, MUAVs as well as spacecraft and other resource constrained platforms that may utilize electric energy as means of propulsion and capability. 
The HILPB system is made up of two major components: a high intensity laser source that is used to transmit the energy, and a power receiver to convert the optical energy into usable electrical energy. Technological advances driven by the manufacturing industry for cutting and welding applications and the defense industry for imaging and directed energy weapons in the past decade have led to a new generation of compact high energy semiconductor lasers that have greatly improved electrical to photonic energy conversion efficiencies. These advances offer a multitude of options to select for the HILPB source. The receiving portion consists of the photovoltaic based system that has been developed around the VMJ cells. The highly efficient silicon based VMJ cells have been developed at the NASA GRC and are capable of sustaining and converting solar energy intensities greater than 2500 suns.

Based on the recent performance results, HILPB is being investigated as the enabling technology to realize a perpetual flight MUAV application for the Air Force Research Laboratory (AFRL) Munitions Directorate at Eglin Air Force Base in Florida. Among other applications, HILPB may also become the enabling technology for exploring the far side of the Moon, by establishing a wireless electrical grid infrastructure for NASA (Ref. 2). To further advance the HILPB technology, different investigations are currently being conducted in an effort to maximize the overall end-to-end system efficiency and increase the delivered power density of the HILPB system. This paper investigates the optimal operating frequency of the semiconductor source laser to be used with the current HILPB power receiver, in order to improve the conversion efficiencies at continuous high energy illumination. To that end, initial spectral characterization of the VMJ cells performed at NASA GRC are presented and used as the basis for formulating the theoretical hypothesis required to optimize the overall efficiency of the HILPB system. The experimental hardware presented in Section 3.0 and the results in Section 4.0 offer specific valuable insight and validate the theoretical hypothesis.

\subsection{The HILPB System}

The HILPB system is constructed around two separate subsystems: one to transmit the energy optically, and another to receive that energy and convert it into electrical energy. While the former half of the HILPB system is accomplished through the use of commercial-off-the-shelf (COTS) high intensity lasers and optics, the latter half is a critical-path component of the HILPB system. The HILPB power receiver has been designed and constructed to withstand high energy illumination, efficiently convert optical energy into electrical energy, dissipate the thermal energy (undesirable byproduct), all while maintaining a practical form factor for system applicability.

The HILPB receiver has been developed around the VMJ cells, a highly efficient photovoltaic technology that has been developed by scientists at NASA GRC for use in photovoltaic concentrator systems. Utilizing a vertical configuration of p+nn+ unit junctions (see Fig. 1), the VMJ photovoltaic cells offer unique advantages over the conventional planer solar cells; a typical cell has an area of approximately $0.8 \mathrm{~cm}^{2}$ and can withstand solar intensities that exceed 2500 suns. Various tests have been conducted at NASA GRC's Large Area Pulsed Solar Simulator (LAPSS) to characterize a single 40-junction VMJ cell, with the results of these tests depicted in Figure 2. Utilizing flash tests of broadband optical energy, a single VMJ cell is capable of producing $40.4 \mathrm{~W}$ at $24 \mathrm{~V}$ from transient flash illuminations of $211 \mathrm{~W} / \mathrm{cm}^{2}$ with an optical to electrical conversion efficiency of 20 percent.

The current HILPB receiver has been designed and constructed for the in-air refueling capability of perpetual flight MUAVs, a terrestrial military application as described in Section 1.0. The design requirements for integrating the VMJ cells with a high performance thermal management system

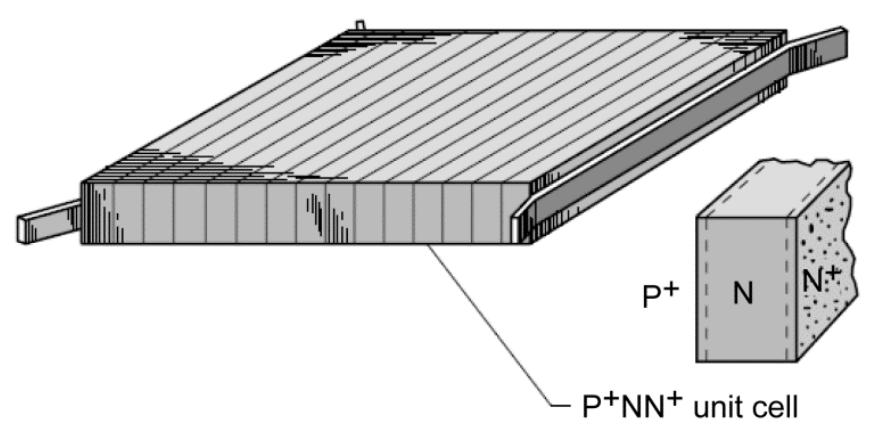

Figure 1.-A 40-junction silicon VMJ photovoltaic cell.

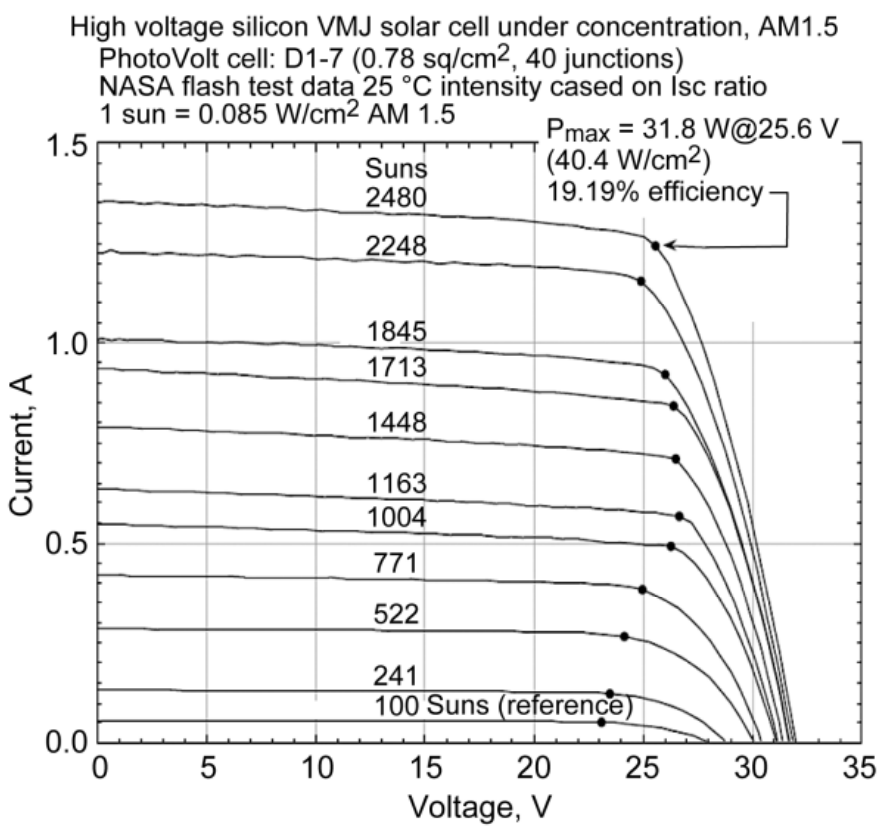

Figure 2.-Silicon VMJ I-V curves at LAPSS (100 to 2500 Suns). 


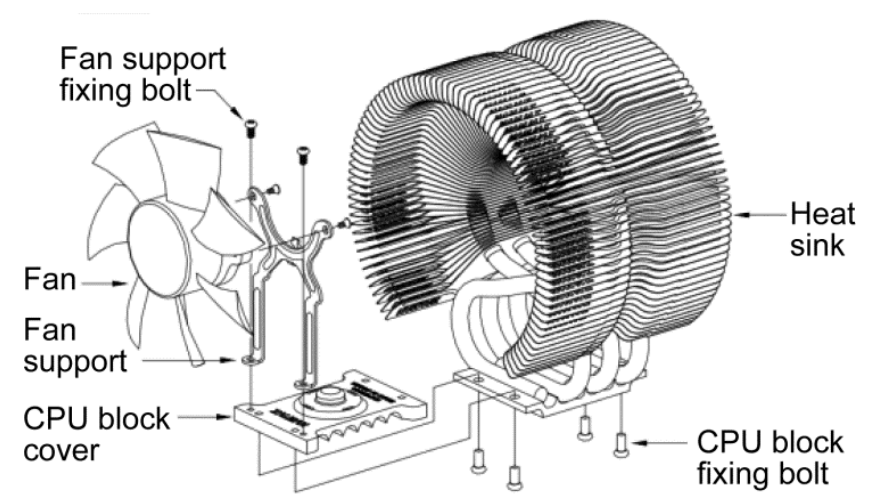

Figure 3.-Zalman heat pipe unit.

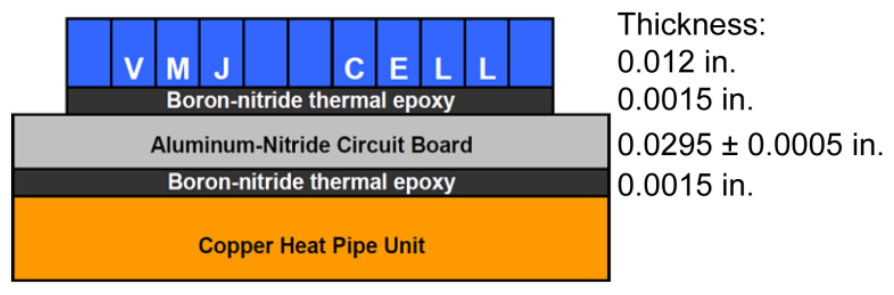

Figure 4.-Cross-sectional stackup of the power receiver.

had to meet stringent size and weight constraints, while addressing the following design challenges: sufficient thermal dissipation for the excess heat energy, low resistivity electrical connections, electrical isolation for the VMJ cells and the routing of the wire interconnections (Refs. 3 to 7). To address the thermal challenge, the prototype receiver implemented a COTS Zalman microprocessor heat pipe unit, which was modified to utilize the airflow from the propeller in order to maximize the surface cooling effect as illustrated in Figure 3. To avoid stress and fracturing during thermal cycles, the VMJ cells are mounted on the thermal management system using a series of epoxies and substrate materials with similar coefficients of thermal expansion. A ferrite-nickel-cobalt alloy wire was used to route the electrical paths between the photovoltaic cells. A cross-sectional illustration of the receiver stack-up is shown Figure 4.

A typical VMJ cell is constructed using an array of miniature silicon vertical junction unit cells, which are integrally bonded and series connected, as illustrated in Figure 1. With vertical oriented junctions, the thickness of the cell is not dependent on the semiconductor material of the wafer, but can be adjusted during manufacturing to optimize the cell's overall performance by tuning the penetration depth. These cells are also known as edge-illuminated multi-junction cells due to their orientation to illumination, since the illuminated face of the cell is oriented at the side of the $\mathrm{p}^{+} \mathrm{nn}+$ junctions. Depending on the end application, the total number of junctions can be varied at the manufacturing stage in order to meet the desired bus voltage requirements. A 40 -junction
VMJ cell has an area of $0.8 \mathrm{~cm}^{2}$ and a nominal load voltage of 24 VDC. This structural design allows for high packing densities when constructing an array, and makes the VMJ technology ideal for use in high power density conversion systems.

The rugged high voltage VMJ cell technology offers a linear low series parasitic resistance at high intensities, which contributes to the high overall conversion efficiency. The edge-illuminated design and construction of the VMJ cell offers a major and unique advantage, as there is no need for electrical contacts obscuring the illuminated face. With no sheet resistivity components, there is more convertible surface area for the photonic energy to enter the cell and less potential for carrier losses. Furthermore, the spectral response at low and high frequencies is improved due to the equal collection probability of an excess carrier to be generated at any depth from the impinging energy (Refs. 8 and 9).

Although a variety of semiconductor materials may be used to manufacture the VMJ cell, a silicon based cell was selected for this particular application due to the high technology readiness level (TRL) to construct a system demonstration. The selection of the wafer composition used to manufacture the VMJ cell affects the complete performance and architecture of the HILPB system as it is directly responsible for the spectral and thermal response of the power beaming receiver. For a silicon based VMJ cell, the thermal derating response appears to be linear in nature since its output power density decreases by less than 1 percent for every $10^{\circ}$ of temperature change, as illustrated in Figure 5.

Maximizing the conversion efficiency and power density of the HILPB system is directly depended on matching the wavelength of the source laser with the frequency response of the VMJ cell under high levels of illumination. The band-gap of the VMJ cell can be determined directly from the semiconductor material used in the manufacturing process. These particular VMJ cells were constructed using silicon wafers, and the characteristic frequency response of the cell is depicted in Figure 6 as obtained from LAPSS. The silicon spectral response of the VMJ cell clearly illustrates that a near infra-red (NIR) laser with a wavelength in the vicinity of $1000 \mathrm{~nm}$ would maximize the output performance of the power receiver.

One key aspect that is illustrated by the quantum efficiency plot shown in Figure 6 is the specific optimal conversion frequency of a VMJ cell. The quantum efficiency and thus the conversion efficiency of a VMJ cell increases as the wavelength of the incident photons approaches the band gap for silicon. The band gap for silicon ranges from 1.125 to $1.2 \mathrm{eV}$, depending on its crystalline structure, in this particular case the peak response is approximately $1000 \mathrm{~nm}$. Based on the quantum efficiency peak range of Figure 6, if incident laser energy in the vicinity of 800 to $1000 \mathrm{~nm}$ is used with a VMJ cell, its theoretical conversion efficiency may approach 50 to 60 percent. 


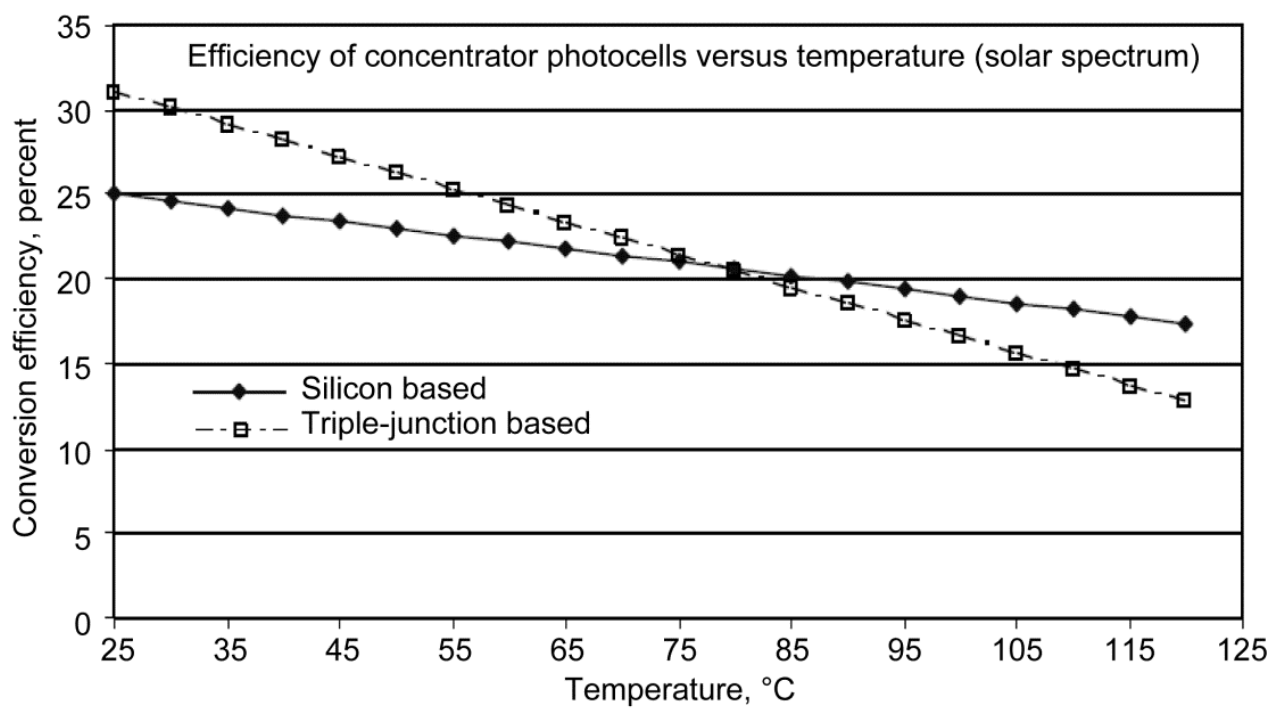

Figure 5.-Silicon VMJ temperature derating.

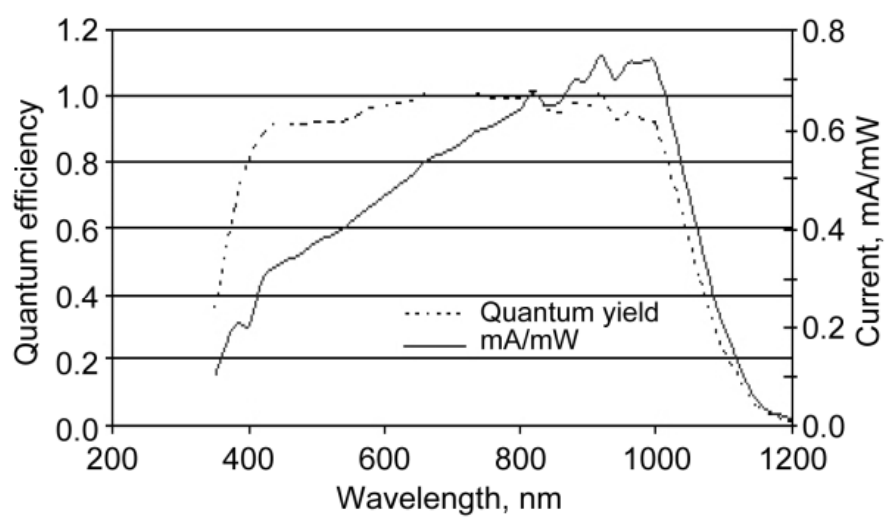

Figure 6.-Silicon spectral response.

The linear transient and steady state behavior of a typical silicon based VMJ cell theoretically should be maintained even at high laser power concentrations. The peak conversion efficiency at high intensities may be affected since high injections levels may cause the band gap to narrow due to the change in the carrier generation and recombination process, where the Shockley equations describing the current-voltage relationship of p-n junctions become less applicable. Hence, in order to maintain high conversion efficiency at high intensity levels the energy wavelength must be within this nonlinear band gap (Refs. 10 and 11).

It must be noted here that for semiconductor materials, the coefficient of absorption decreases significantly beyond the cutoff wavelength of the impinging energy, as illustrated by the knee curves of Figure 7. At high injection levels the narrow band-gap of silicon may be affected as there is a possibility that the knee of the silicon curve may shift, further affecting the conversion efficiency of the VMJ cells. In addition, there are two scenarios that may limit the overall

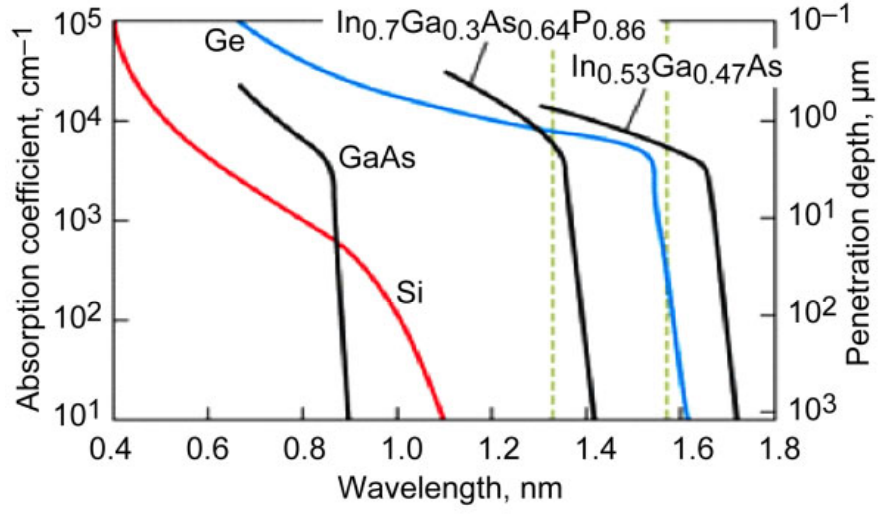

Figure 7.-Optical absorption for various semiconductor materials.

conversion efficiency and creating additional thermal stress due to the excess heat byproduct. First, the thickness of the semiconductor material may lead to saturation by limiting the total depth of penetration for the impinging energy, thus limiting the efficient photoelectric conversion. Another scenario that may limit the overall conversion efficiency is the increase in wavelength of the impinging light due to the oblique collisions in the capture cross section as the light penetrates through the silicon material. Empirical investigation of the optimal frequency under high levels of steady-state illumination is necessary to validate the transient response curves.

\subsection{Experiment Design}

The best range of narrow band illumination for the VMJ cell was identified based on the quantum efficiency plot shown in Figure 6 . The particular peak frequency must be verified experimentally to ensure that saturation does not occur at 

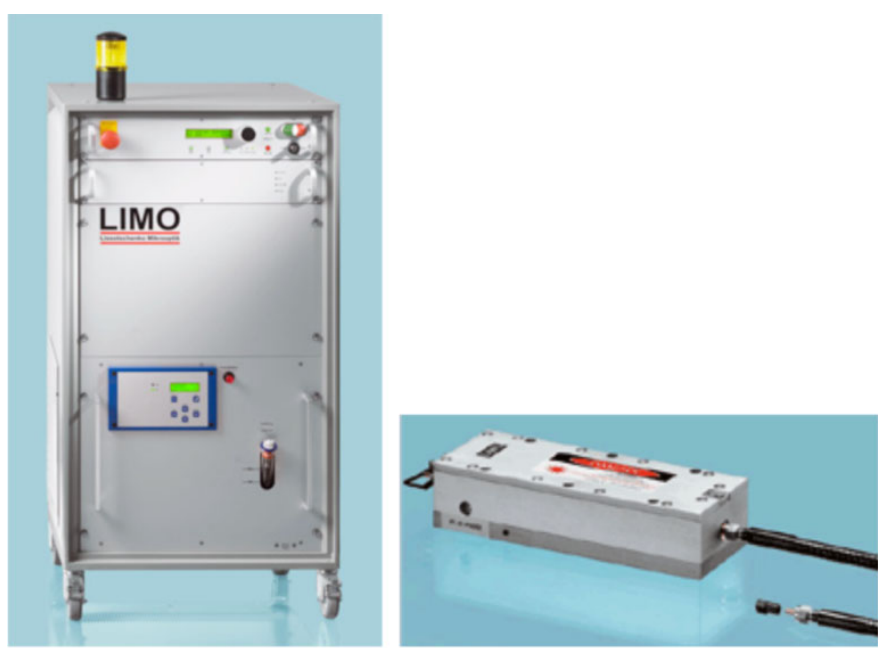

Figure 8.-LIMO water-cooled turn-key laser system.

continuous high intensities. The experimental set-up consists of a single VMJ cell receiver and three similar continuouswave, fiber-coupled semiconductor lasers with distinct operating frequencies. Since the current technology does not offer a tunable laser at the wavelength range of interest, three standard high intensity lasers were selected from Lissotschenko Mikrooptik GmbH (LIMO) Laser Applications Laboratory in Dortmund, Germany. The wavelengths of the three lasers were selected to be in close range of the VMJ narrow band gap: $808 \mathrm{~nm}$ (LIMO70-F200-DL808), $940 \mathrm{~nm}$ (LIMO70-F200-DL940), and $976 \mathrm{~nm}$ (LIMO70-F200DL976). All three LIMO lasers are complete systems that include power, control, water chiller, and a diode module; a typical LIMO laser system is shown in Figure 8.

The experimental rig consists of the following components: a single VMJ cell receiver mounted to a 3-axis translational positioned system, laser source, adjustable mechanical stage for the optical fiber, cooling fan, custom data acquisition electronics (DATAQ), and a logging personal computer. A pictorial representation of the experimental set-up is illustrated in Figure 9.

In order to characterize the performance of the receiver, an automated, high performance data acquisition (DATQ) system was designed and constructed to record voltage, current, and temperature information simultaneously. The DATAQ system is made up of three individual subsystems: an active variable load that can be adjusted from open-circuit to short-circuit in order to trace the characteristic I-V curve, sensing circuitry and data processing. The focus during the design of the DATAQ system was to achieve high data integrity and reliability. To that end, many design decisions were made to improve the accuracy and quality of the measured states, such as using open-loop/Hall-Effect current sensors to minimize noise interference. For accuracy purposes, the information is represented by 16-bit words (19 bits effective). In addition, to improve the overall system reliability, the DATAQ has been divided into two separate printed circuit boards (PCB) as

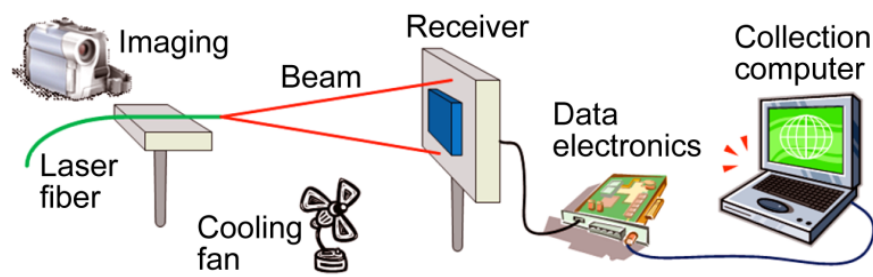

Figure 9.-Single VMJ cell power beaming test rig.

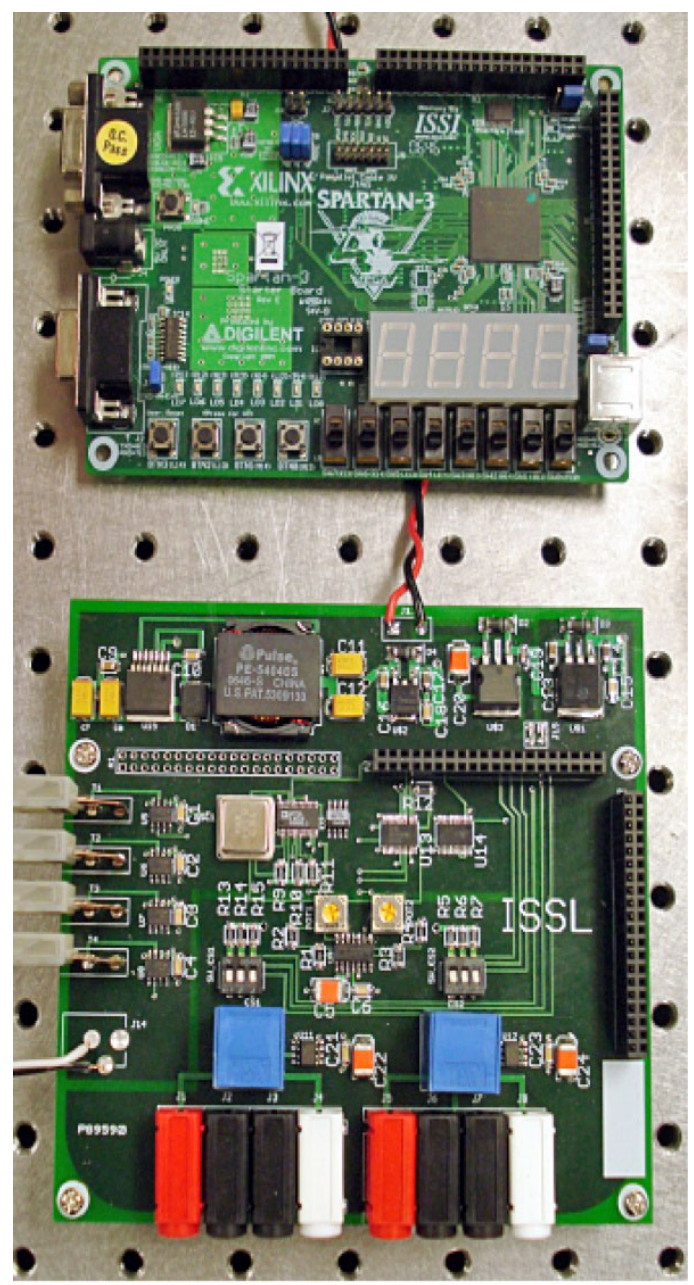

Figure 10.-Custom, high performance data acquisition system (DATAQ).

depicted in Figure 10, with special attention given to the board layout phase of the design. Data logging and processing is achieved by utilizing a Xilinx Spartan-3 development board, which includes a field programmable gate array (FPGA) that contains a total of $200 \mathrm{k}$ gates. Figure 11 illustrates the functional block diagram of the DATAQ system. The data transmits via the RS-232 interface to a personal computer at a rate of $6 \mathrm{~Hz}$. Lastly, a custom Graphical User Interface (GUI) was designed to plot and display the I-V characteristic curve of the receiver in real-time. 


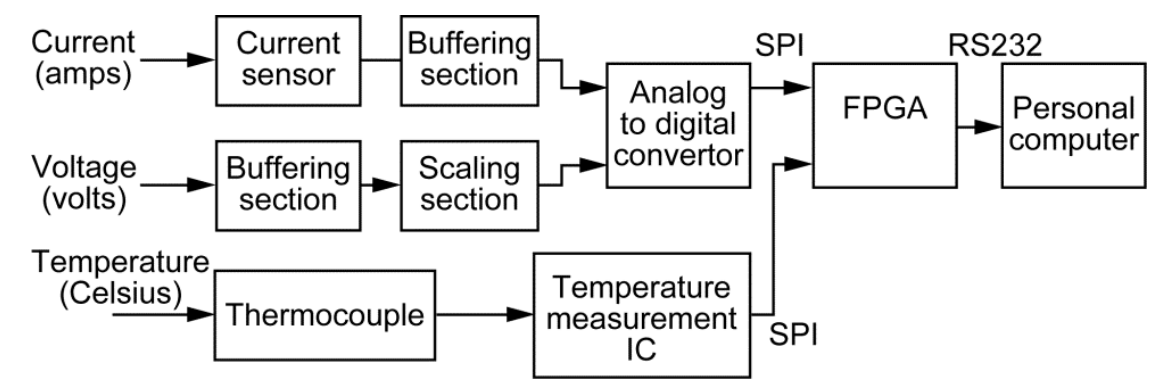

Figure 11.-DATAQ - Functional block diagram.

For experimental consistency purposes, all three lasers have a $70 \mathrm{~W}$ capacity and the fiber is $200 \mu \mathrm{m}$ in diameter. All optical equipment was fastened down to the work surface, and only one laser fiber was used for all experiments; this way the laser diode module became the only hardware variable during each test trial. An initial alignment was performed prior to conducting all tests, by using the laser pilot beam to visually align the laser beam at the center of the VMJ cell. At low laser intensities the receiver was adjusted using the 3-axis translational positioner for peak output power generation. For all tests, the laser power was increased to cover the full power range of each LIMO laser system. The point of maximum output power was achieved when $26 \mathrm{~W}$ of laser energy directly illuminated the VMJ cell, overfilling its surface area.

\subsection{Experimental Results}

The experimental results from the conducted tests are illustrated in Tables I, II, and III, and the maximum output power attained is highlighted in each corresponding table.

TABLE I.-940 nm WAVELENGTH RESULTS

\begin{tabular}{|c|c|c|c|}
\hline \multicolumn{5}{|c|}{ LIMO70-F200-DL940 } \\
\hline $\begin{array}{c}\text { Current } \\
\text { setpoint, } \\
\text { A }\end{array}$ & $\begin{array}{c}\text { Rated optical } \\
\text { power, } \\
\text { W }\end{array}$ & $\begin{array}{c}\text { Operating } \\
\text { optical power, } \\
\text { W }\end{array}$ & $\begin{array}{c}\text { Adj. optical } \\
\text { window } \\
\text { transmittance, } \\
\text { W }\end{array}$ \\
\hline 10 & 9.9 & 9.207 & 8.608545 \\
20 & 25.7 & 23.901 & 22.347435 \\
30 & 40.9 & 38.037 & 35.564595 \\
40 & 55.1 & 51.243 & 47.912205 \\
50.8 & 70 & 65.1 & 60.8685 \\
\hline \multicolumn{4}{|c|}{ LIMO70-F200-DL940 } \\
\hline Impinging & VMJ peak & Conversion & Receiver \\
optical power, & power, & efficiency, & temperature, \\
W & W & 41.54 & 24.4 \\
\hline 3.6586 & 1.5198 & 37.27 & 25 \\
9.4977 & 3.5398 & 33.23 & 27.6 \\
15.1150 & 5.0675 & 30.26 & 30.1 \\
20.3627 & 6.1611 & 26.39 & 32 \\
25.8691 & 6.8263 & \multicolumn{3}{c}{}
\end{tabular}

TABLE II.-976 nm WAVELENGTH RESULTS

\begin{tabular}{|c|c|c|c|}
\hline \multicolumn{4}{|c|}{ LIMO70-F200-DL976 } \\
\hline $\begin{array}{c}\text { Current } \\
\text { setpoint, } \\
\mathrm{A}\end{array}$ & $\begin{array}{c}\text { Rated optical } \\
\text { power, } \\
\mathrm{W}\end{array}$ & $\begin{array}{c}\text { Operating } \\
\text { optical power, } \\
\mathrm{W}\end{array}$ & $\begin{array}{c}\text { Adj. optical } \\
\text { window } \\
\text { transmittance, } \\
\mathrm{W}\end{array}$ \\
\hline 10 & 9.8 & 9.114 & 8.52159 \\
20 & 25.4 & 23.622 & 22.08657 \\
30 & 40.9 & 38.037 & 35.564595 \\
40 & 56 & 52.08 & 48.6948 \\
50 & 70 & 65.1 & 60.8685 \\
\hline \multicolumn{4}{|c|}{ LIMO70-F200-DL976 } \\
\hline Impinging & VMJ peak & Conversion & Receiver \\
optical power, & power, & efficiency, & temperature, \\
W & W & 42.74 & 24.1 \\
\hline 3.6217 & 1.5481 & 37.71 & 24.7 \\
9.3868 & 3.5402 & 34.22 & 27.5 \\
15.1150 & 5.1722 & 31.15 & 30.1 \\
20.6953 & 6.4459 & 28.00 & 32.6 \\
25.8691 & 7.2430 & \multicolumn{3}{c}{} \\
\hline \multicolumn{4}{|c|}{}
\end{tabular}

TABLE III.-808 nm WAVELENGTH RESULTS

\begin{tabular}{|c|c|c|c|}
\hline \multicolumn{5}{|c|}{ LIMO70-F200-DL808 } \\
\hline $\begin{array}{c}\text { Current } \\
\text { setpoint, } \\
\text { A }\end{array}$ & $\begin{array}{c}\text { Rated optical } \\
\text { power, } \\
\text { W }\end{array}$ & $\begin{array}{c}\text { Operating } \\
\text { optical power, } \\
\text { W }\end{array}$ & $\begin{array}{c}\text { Adj. optical } \\
\text { window } \\
\text { transmittance, } \\
\text { W }\end{array}$ \\
\hline 10 & 1.7 & 1.581 & 1.478235 \\
20 & 20.3 & 18.879 & 17.651865 \\
30 & 38.9 & 36.177 & 33.825495 \\
40 & 56.4 & 52.452 & 49.04262 \\
49.4 & 70 & 65.1 & 60.8685 \\
\hline \multicolumn{4}{|c|}{ LIMO70-F200-DL808 } \\
\hline Impinging & VMJ peak & Conversion & Receiver \\
optical power, & power, & efficiency, & temperature, \\
W & W & \% \\
\hline 0.6282 & 0.3131 & 49.83 & 22.5 \\
7.5020 & 1.8050 & 24.06 & 28.7 \\
14.3758 & 3.0695 & 21.35 & 35.4 \\
22.8431 & 3.9837 & 19.11 & 41.8 \\
25.8691 & 4.6798 & 18.09 & 47.2 \\
\hline
\end{tabular}


Furthermore, the output power characteristic I-V curves corresponding to each LIMO laser system are illustrated in Figure 12. Corresponding images of the experiments are also shown in Figure 12, and if viewing this document in color please note that the images are shown in three different colors even though all three laser beams are in the NIR region, which is invisible to the human eye. The coloring effect is due to the digital camera used during the experiment aliasing the NIR frequencies in the experimental hardware rig.

Figures 13 and 14 illustrate the response at each frequency as a function of input intensity, and conversion efficiency. It is shown here that the response across varying irradiance is fairly linear, while the efficiency curve for the $808 \mathrm{~nm}$ test exhibits a strong decrease above nominally low optical inputs.

The experimental results illustrated in Tables I, II, III, and Figures 12, 13, and 14 illustrates that the $976 \mathrm{~nm}$ wavelength laser offers the optimal performance when used with the silicon based VMJ cells. Furthermore, the $976 \mathrm{~nm}$ wavelength laser offers better efficiency and higher electrical output as depicted in Figure 15 and 16 comparisons, respectively.

An interesting phenomenon is illustrated in Figure 15. The $808 \mathrm{~nm}$ wavelength laser is shown to achieve 50 percent efficiency at lower laser intensities, followed by a drop in efficiency with increasing levels. At first, this is may indicate that the VMJ cell reached saturation. However, that may not be the case since the sharp drop is only associated with the $808 \mathrm{~nm}$ wavelength. The associated hardware pictures also depict a high level of scattering for the $808 \mathrm{~nm}$ tests, which may indicate that some of the laser energy is reflected back and away from the surface of the VMJ cell, and is thus not contributing to the electrical output of the cell.

These data sets may be compared with an earlier experiment conducted with a very similar test setup, but utilizing a LIMO $1064 \mathrm{~nm}$ source laser. In that experiment, the laser source was similarly operated at a peak optical output power of $70 \mathrm{~W}$ (with 25.86 W illuminating the receiver), and after fine tuning the alignment of the receiver the single illuminated VMJ cell was able to deliver $4.08 \mathrm{~W}$ of electrical power. This performance indicates a 15.8 percent optical-to-electrical efficiency, which is below the performance achieved with either the 808, 940 or $976 \mathrm{~nm}$ sources. This is because the $1064 \mathrm{~nm}$ source is beyond the band gap of the silicon VMJ cell, as illustrated in Figure 6.

Lastly, a separate experiment was conducted while at the LIMO laser laboratory in Dortmund, Germany, to determine the highest power density achievable with a single VMJ photovoltaic cell. Using the selected $976 \mathrm{~nm}$ laser system, one VMJ cell produced $10.74 \mathrm{~W}$ from $44.72 \mathrm{~W}$ of impinging laser energy, which is equivalent to an output power density of $13.6 \mathrm{~W} / \mathrm{cm}^{2}$ from $56.6 \mathrm{~W} / \mathrm{cm}^{2}$ of total laser energy. Hence, the total optical-to-electrical conversion efficiency was approximately 24 percent. This represents the highest output power density achieved to date in HILPB, with a single VMJ silicon-based photovoltaic cell.
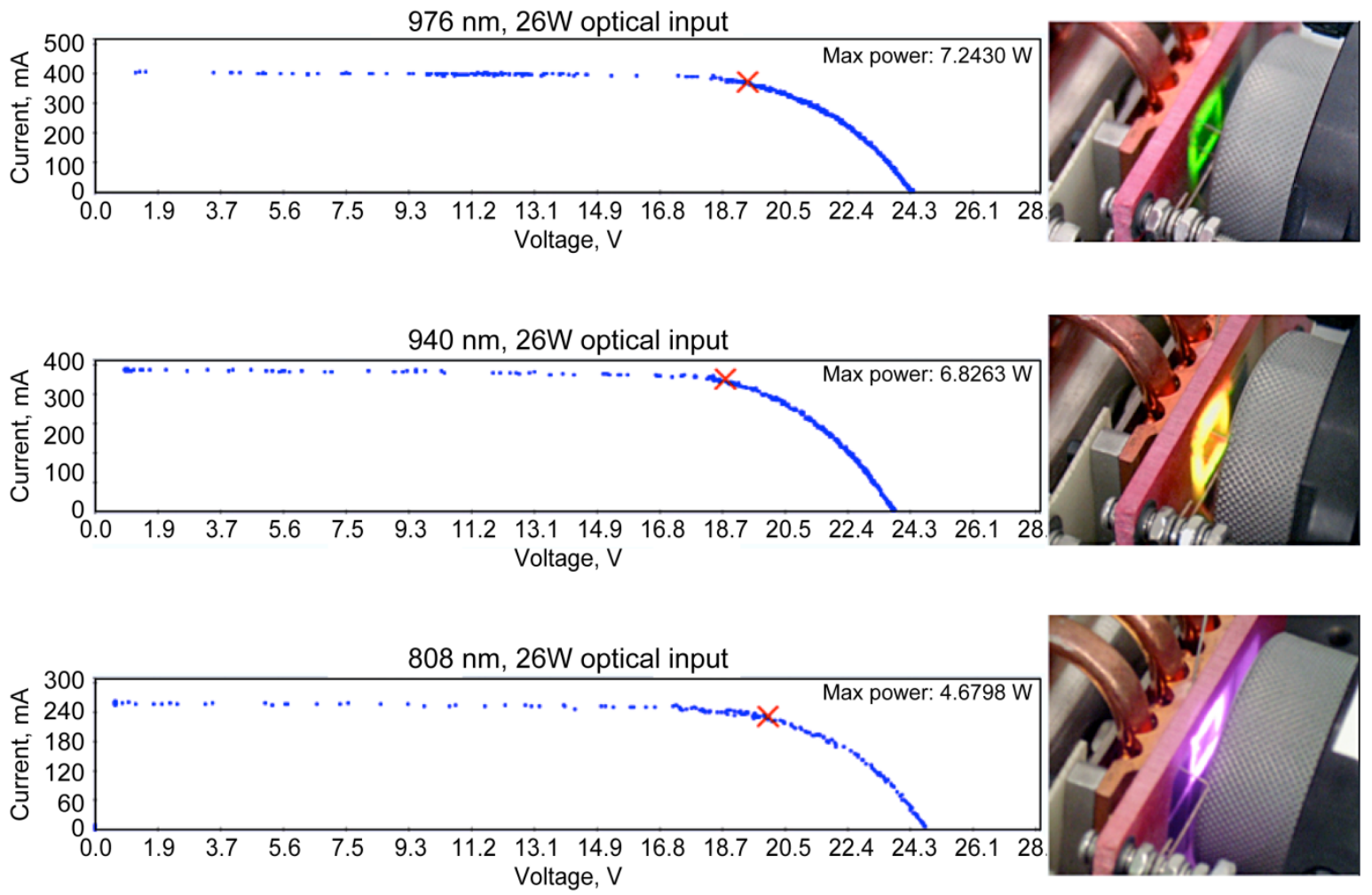

Figure 12.-Wavelength maximum power I-V curves. 

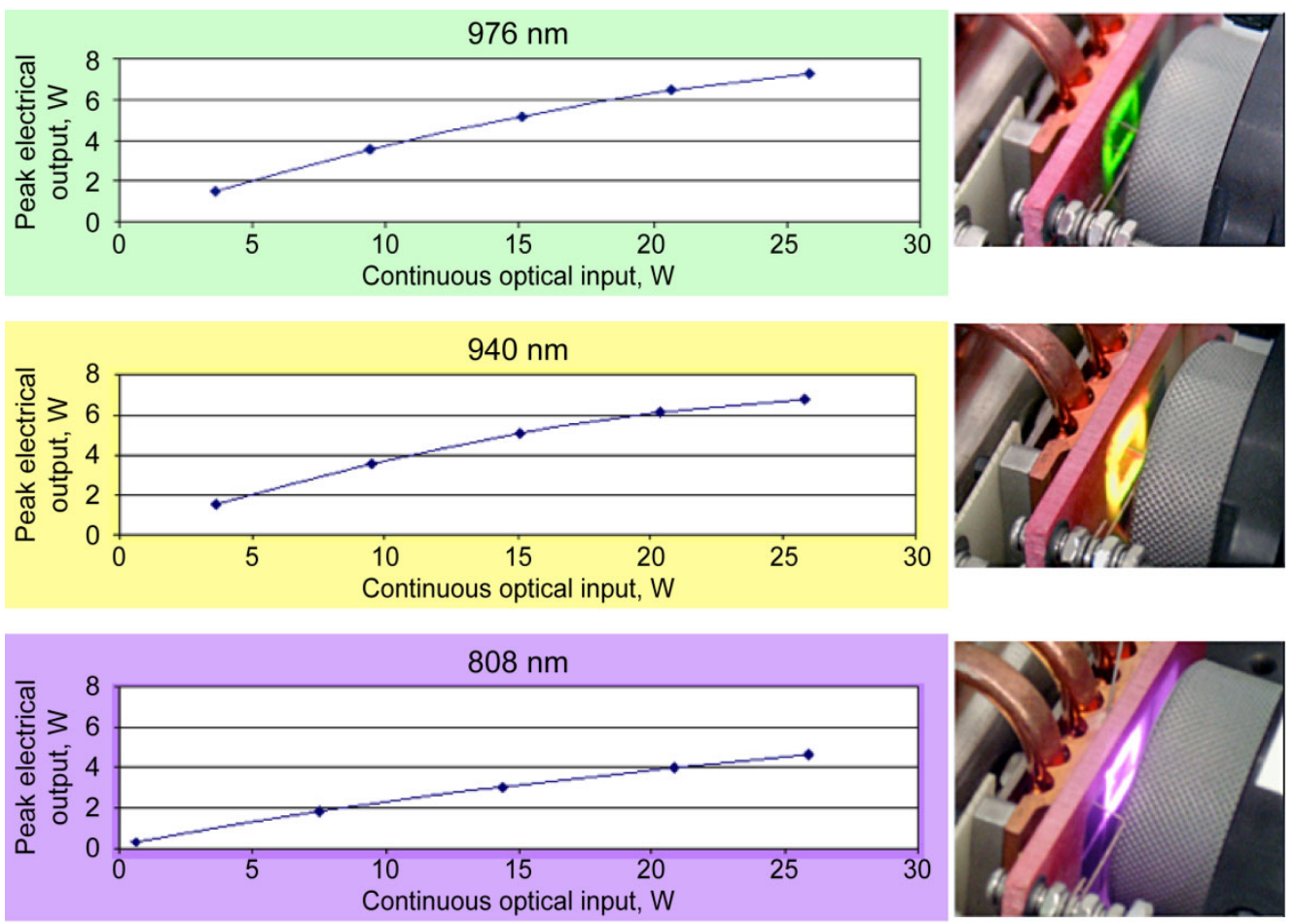

Figure 13.-Wavelength input versus output.
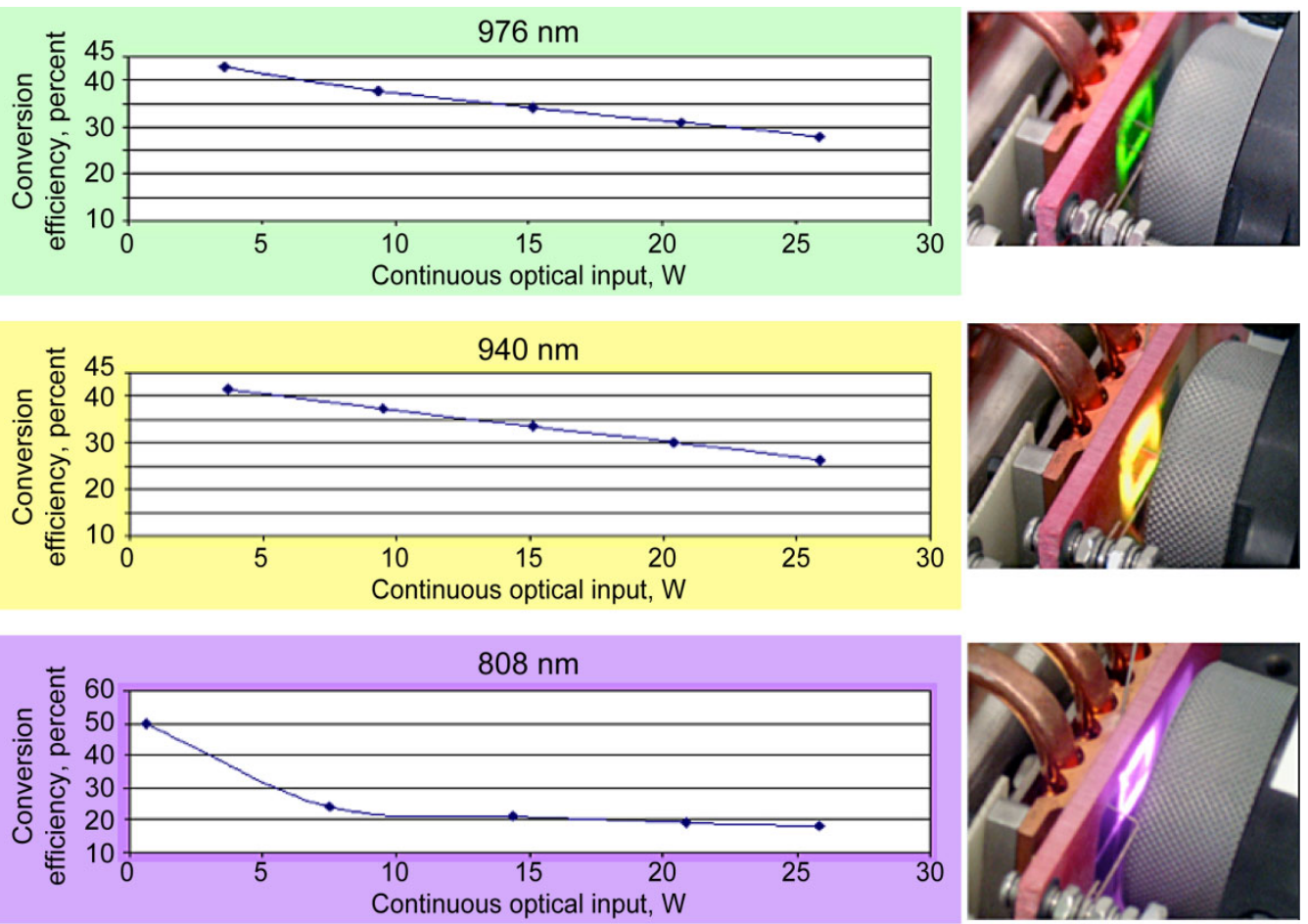

Figure 14.-Wavelength conversion efficiencies. 


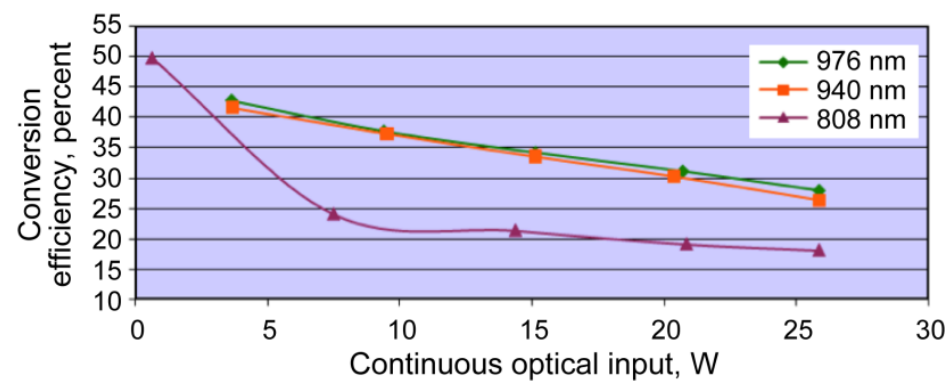

Figure 15.-Wavelength efficiency comparison.

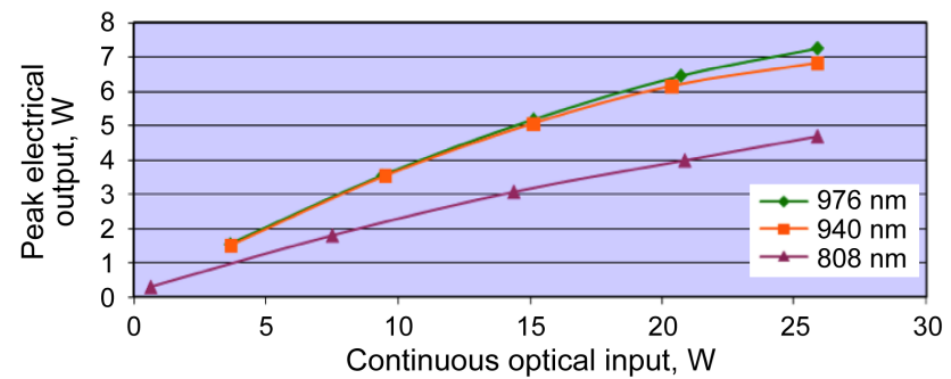

Figure 16.-Wavelength output comparison.

\subsection{Conclusion}

In conclusion the optimal frequency of the laser source to be used with the current HILPB receiver should be in the vicinity of $976 \mathrm{~nm}$, which corresponds favorably to commercially available laser systems. Appreciative responses may be realized at adjacent frequencies including 808, 940, and $1064 \mathrm{~nm}$, but they are significantly reduced when compared with the performance results obtained near $976 \mathrm{~nm}$. This capability may be utilized in a multi-beam/multi-wavelength system, in which the VMJ cells may act as sensors for an acquisition beacon laser operating at an adjacent wavelength to the main beam. Depending on the specific application, the cell design and semiconductor material may also be selected to maximize different design parameters such as high output voltages (high energy band-gaps) or high output currents (low energy bandgaps). These tests also demonstrate the highest output power density achieved thus far at $13.6 \mathrm{~W} / \mathrm{cm}^{2}$.

\section{References}

1. N. Tesla, "The Future of the Wireless Art," Wireless Telegraphy and Telephony, pg. 67-71, 1908.

2. T.H. Nayfeh, B. Fast, D.E. Raible, D. Dinca, N. Tollis, A. Jalics, "High Intensity Laser Power Beaming Architecture for Space and Terrestrial Missions," Proceedings of the 18th AFRL/NASA Advanced Space Propulsion Workshop; November 15-17, 2010; University of Colorado at Colorado Springs, Colorado Springs, Colorado; 2010.

3. D.E. Raible, "High Intesnity Laser Power Beaming for Wireless Power Transmission,” Master's Thesis, Cleveland State University, May 2008.
4. K. Miwa, A. Fukumoto, "First Principles Calculation of the structural, electronic and vibrational properties of gallium nitride and aluminum nitride,” Physical Review B, Vol. 48 No. 11, Sep. 15, 1993.

5. G. Liu, B. Cui, R.J. Chen, "Thermal Expansion Behavior of Copper/Kovar Alloy Composite,” Northeast Univ. Technol. (China). vol. 9, no. 4, pp. 498-501. Dec. 1988.

6. P. Bujard, "Thermal conductivity of boron nitride filled epoxy resins: temperature dependence and influence of sample preparation,” Ciba-Geigy Ltd., Fribourg; Thermal Phenomena in the Fabrication and Operation of Electronic Components: I-THERM '88, InterSociety Conference on; 11-13 May 1988.

7. L. Daoqiang, O.K. Tong, C.P. Wong, "Conductivity mechanisms of isotropic conductive adhesives (ICAs)," Electronics Packaging Manufacturing, IEEE Transactions on [see also Components, Packaging and Manufacturing Technology, Part C: Manufacturing, IEEE Transactions on, vol. 22, no. 3 pp. 223-227, Jul. 1999.

8. B.L. Sater, N.D. Sater, "High voltage silicon VMJ solar cells for up to 1000 suns intensities," Photovoltaic Specialists Conference, 2002. Conference Record of the 29th IEEE, 19-24 May 2002, pp. 1019-1022, ISSN: 10608371, ISBN: 0-7803-7471-1.

9. C. Goradia, B.L. Sater, "A first order theory of the $p /+/-n-$ $\mathrm{n} /+$ / edge-illuminated silicon solar cell at very high injection levels,” IEEE Transactions on Electron Devices. Vol. ED24, pp. 342-351. Apr. 1977.

10. S. Noor Mohammad, S. Abidi, "Theory of saturation photocurrent and photovoltage in p-n junction solar cells,” J. of Applied Physics. vol. 61, pp. 4909-4919. 15 May, 1987.

11. E.D. Palik, "Handbook of Optical Constants of Solids," Academic Press, NY, 1985. 


\begin{tabular}{|c|c|c|}
\hline \multicolumn{2}{|c|}{ REPORT DOCUMENTATION PAGE } & $\begin{array}{l}\text { Form Approved } \\
\text { OMB No. 0704-0188 }\end{array}$ \\
\hline \multicolumn{3}{|c|}{ 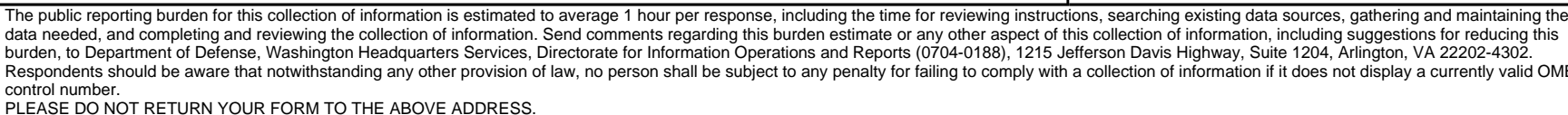 } \\
\hline $\begin{array}{l}\text { 1. REPORT DATE (DD-MM-YYYY) } \\
01-03-2012\end{array}$ & $\begin{array}{l}\text { 2. REPORT TYPE } \\
\text { Technical Memorandum }\end{array}$ & 3. DATES COVERED (From - To) \\
\hline \multirow{3}{*}{\multicolumn{2}{|c|}{$\begin{array}{l}\text { 4. TITLE AND SUBTITLE } \\
\text { Optical Frequency Optimization of a High Intensity Laser Power Beaming System Utilizing } \\
\text { VMJ Photovoltaic Cells }\end{array}$}} & 5a. CONTRACT NUMBER \\
\hline & & 5b. GRANT NUMBER \\
\hline & & 5c. PROGRAM ELEMENT NUMBER \\
\hline \multirow{3}{*}{\multicolumn{2}{|c|}{$\begin{array}{l}\text { 6. AUTHOR(S) } \\
\text { Raible, Daniel, E; Dinca, Dragos; Nayfeh, Taysir, H. }\end{array}$}} & 5d. PROJECT NUMBER \\
\hline & & 5e. TASK NUMBER \\
\hline & & $\begin{array}{l}\text { 5f. WORK UNIT NUMBER } \\
\text { WBS 439432.07.01.17.02 }\end{array}$ \\
\hline \multicolumn{2}{|c|}{$\begin{array}{l}\text { 7. PERFORMING ORGANIZATION NAME(S) AND ADDRESS(ES) } \\
\text { National Aeronautics and Space Administration } \\
\text { John H. Glenn Research Center at Lewis Field } \\
\text { Cleveland, Ohio 44135-3191 }\end{array}$} & $\begin{array}{l}\text { 8. PERFORMING ORGANIZATION } \\
\text { REPORT NUMBER } \\
\text { E-18011 }\end{array}$ \\
\hline \multirow{2}{*}{\multicolumn{2}{|c|}{$\begin{array}{l}\text { 9. SPONSORING/MONITORING AGENCY NAME(S) AND ADDRESS(ES) } \\
\text { National Aeronautics and Space Administration } \\
\text { Washington, DC 20546-0001 }\end{array}$}} & $\begin{array}{l}\text { 10. SPONSORING/MONITOR'S } \\
\text { ACRONYM(S) } \\
\text { NASA }\end{array}$ \\
\hline & & $\begin{array}{l}\text { 11. SPONSORING/MONITORING } \\
\text { REPORT NUMBER } \\
\text { NASA/TM-2012-217256 }\end{array}$ \\
\hline
\end{tabular}

\section{DISTRIBUTIONIAVAILABILITY STATEMENT}

Unclassified-Unlimited

Subject Categories: 33, 36, and 74

Available electronically at http://www.sti.nasa.gov

This publication is available from the NASA Center for AeroSpace Information, 443-757-5802

\section{SUPPLEMENTARY NOTES}

\section{ABSTRACT}

An effective form of wireless power transmission (WPT) has been developed to enable extended mission durations, increased coverage and added capabilities for both space and terrestrial applications that may benefit from optically delivered electrical energy. The high intensity laser power beaming (HILPB) system enables long range optical "refueling" of electric platforms such as micro unmanned aerial vehicles (MUAV), airships, robotic exploration missions and spacecraft platforms. To further advance the HILPB technology, the focus of this investigation is to determine the optimal laser wavelength to be used with the HILPB receiver, which utilizes vertical multi-junction (VMJ) photovoltaic cells. Frequency optimization of the laser system is necessary in order to maximize the conversion efficiency at continuous high intensities, and thus increase the delivered power density of the HILPB system. Initial spectral characterizations of the device performed at the NASA Glenn Research Center (GRC) indicate the approximate range of peak optical-to-electrical conversion efficiencies, but these data sets represent transient conditions under lower levels of illumination. Extending these results to high levels of steady state illumination, with attention given to the compatibility of available commercial off-the-shelf semiconductor laser sources and atmospheric transmission constraints is the primary focus of this paper. Experimental hardware results utilizing high power continuous wave (CW) semiconductor lasers at four different operational frequencies near the indicated band gap of the photovoltaic VMJ cells are presented and discussed. In addition, the highest receiver power density achieved to date is demonstrated using a single photovoltaic VMJ cell, which provided an exceptionally high electrical output of $13.6 \mathrm{~W} / \mathrm{cm}^{2}$ at an optical-to-electrical conversion efficiency of 24 percent. These results are very promising and scalable, as a potential $1.0 \mathrm{~m}^{2} \mathrm{HILPB}$ receiver of similar construction would be able to generate $136 \mathrm{~kW}$ of electrical power under similar conditions.

\section{SUBJECT TERMS}

Optics; Photonics; Laser power beaming; Wireless power transmission

\begin{tabular}{|c|c|c|c|c|c|}
\hline \multicolumn{3}{|c|}{ 16. SECURITY CLASSIFICATION OF: } & \multirow{2}{*}{$\begin{array}{l}\text { 17. LIMITATION OF } \\
\text { ABSTRACT } \\
\text { UU }\end{array}$} & \multirow{2}{*}{$\begin{array}{l}\text { 18. NUMBER } \\
\text { OF } \\
\text { PAGES } \\
15\end{array}$} & \multirow{2}{*}{$\begin{array}{l}\text { 19a. NAME OF RESPONSIBLE PERSON } \\
\text { STI Help Desk (email:help@sti.nasa.gov) } \\
\text { 19b. TELEPHONE NUMBER (include area code) } \\
\text { 443-757-5802 }\end{array}$} \\
\hline $\begin{array}{l}\text { a. REPORT } \\
\mathrm{U}\end{array}$ & $\begin{array}{l}\text { b. ABSTRACT } \\
\text { U }\end{array}$ & $\begin{array}{l}\text { c. THIS } \\
\text { PAGE } \\
\text { U }\end{array}$ & & & \\
\hline
\end{tabular}


